\title{
Altıncı Sınıf Öğrencilerinin Matematik Öğrenme Yaklaşımları ve Algıladıkları Öğretmen Yapıcı Duygusal Desteği İle Matematik Başarıları Arasındaki İlişski
}

\section{Dr. Deniz Kaya ${ }^{1 *}$}

Geliş tarihi: 17.03 .2020

Kabul tarihi: 07.04.2020

\section{Atıf bilgisi:}

IBAD Sosyal Bilimler Dergisi

Sayı: $7 \quad$ Sayfa: $358-371$

Yıl: 2020 Dönem: Yaz

This article was checked by Turnitin. Similarity Index $15 \%$

Bu makalede araştırma ve yayın etiğine uyulmuştur.

${ }^{1} \mathrm{MEB}$, Türkiye, denizkaya50@yahoo.com ORCID ID 0000-0002-7804-1772

\section{ÖZ}

$\mathrm{Bu}$ çalışmada, altıncı sınıf öğrencilerinin matematik öğrenme yaklaşımları ve algıladıkları öğretmen yapıcı duygusal desteği ile matematik başarıları arasındaki ilişki incelenmiștir. Araștırmaya 416 altıncı sınıf öğrencisi katılmıștır. Araștırmaya katılan öğrencilerin \%54.3'ü (n=226) kız, \%45.7'si (n=190) erkektir. Çalışmada veri toplama aracı olarak, Algılanan Öğretmen Yapıcı Duygusal Destek ile Matematik Öğrenme Yaklaşımları ölçekleri kullanılmıştır. Öğrencilerin matematik başarılarını belirlemek için dönem sonu matematik not ortalamaları kullanılmıștır. Verilerin analizinde, Pearson momentler çarpımı korelâsyon katsayısı ve çoklu doğrusal regresyon kullanılmıştır. Elde edilen bulgulara göre, altıncı sınıf öğrencilerinin matematik başarıları ile algılanan öğretmen yapıcı duygusal destek, derinlemesine öğrenme yaklaşımı, yüzeysel öğrenme yaklaşımı ve stratejik öğrenme yaklaşımı arasında anlamlı ilişkiler tespit edilmiştir. Çoklu regresyon analiz sonuçlarına göre, matematik öğrenme yaklaşımları ile algılanan öğretmen yapıcı duygusal destek matematik başarısındaki varyansın \%26'sını açıklamıştır. Aynı zamanda algılanan öğretmen yapıcı duygusal destek ile öğrenme yaklassımları matematik başarısının anlamlı yordayıcıları olmuştur. Elde edilen bulgular ışığında birtakım önerilerde bulunulmuştur.

Anahtar Kelimeler: Altıncı Sınıf, Duygusal Destek, Matematik Başarısı, Öğrenme Yaklaşımı

*Sorumlu yazar 


\section{Dr. Deniz Kaya ${ }^{1^{*}}$}

First received: 17.03 .2020 Accepted: 07.04.2020

\section{Citation:}

IBAD Journal of Social Sciences

Issue: 7

Year: 2020

Pages: 358-371

Session: Summer

This article was checked by Turnitin. Similarity Index 15\%

${ }^{1} \mathrm{MNE}$, Turkey, denizkaya50@yahoo.com ORCID ID 0000-0002-7804-1772

\footnotetext{
* Corresponding Author
}

\begin{abstract}
In this study, the relationship between sixth grade students' mathematics learnig approaches and perceived teacher constructive affective support and mathematics achievements was examined. 416 sixth grade students participated in the study. $54.3 \%(\mathrm{n}=226)$ of the students participating in the research are girls and $45.7 \%$ $(\mathrm{n}=190)$ are boys. In the study, Perceived Teacher Constructive Affective Support and Mathematics Learning Approaches scales were used as data collection tools. Mathematics grade point averages were used to determine the mathematics achievement of the students. In analyzing the data, Pearson moments multiplication correlation coefficient and multiple linear regression were used. According to the findings, significant relationships were found between sixth grade students' mathematics achievements and perceived teacher constructive affective support, deep learning approach, surface learning approach and strategic learning approach. According to multiple regression analysis results, mathematics learning approaches and perceived teacher constructive affective support explained $26 \%$ of the variance in mathematics achievement. In addition, perceived teacher constructive affective support and learning approaches have been significant predictors of mathematics achievement. In the light of the findings, some suggestions were made.
\end{abstract}

Keywords: Sixth Grade, Affective Support, Mathematics Achievement, Learning Approach 


\section{GİRIŞ}

Matematiksel bilgi ve becerilere duyulan gereksinim günlük yaşam durumlarından üst düzey çalıșmalara kadar geniş bir alanı kapsamaktadır. Özellikle içinde bulunduğumuz enformasyon çağında teknolojinin yükselişine bağlı olarak matematik önemli bir kullanım aracı haline dönüşmüştür. Dolayısıyla bireyler için matematiksel bilgi ve becerilere duyulan gereksinimler sürekli artarken çok sayıda ülke matematikte daha başarılı bireyler yetiştirebilme yarışına girmiştir (NCTM, 2014). Bu kapsamda, birçok ülke matematik öğretim programlarının temel felsefelerinde bir dizi köklü değişikliklere giderek 21. yüzyıl becerileri olarak anılan problem çözme, eleştirel düşünme, yaratıcılık, akıl yürütme, bilgi okuryazarlığı, öz yeterlik, girişim, öz yönetim, muhakeme etme, iletişim, işbirliği, esneklik ve uyum yeteneği gibi becerileri öğretim programlarının merkezine almıştır (NRC, 2012). Bu durumun en önemli nedenleri arasında matematiği etkili kullanabilen bireylere sahip toplumların geleceklerini șekillendirirken daha fazla söz sahibi olma arzusu yer almaktadır (NCTM, 2000). Bundan dolayı günümüzde matematik okuryazarı olmak, matematiksel becerilere sahip olmak, matematiğin doğasını anlamak ve matematikte başarılı olmak daha da önem kazanmıştır. Ancak tüm bu olumlu bakış açılarına ve matematik öğretim programlarındaki değişimlere rağmen uluslararası kuruluşların düzenli aralıklarla yayınladığı raporlarda birçok ülkenin matematik başarılarının arzu edilenin oldukça gerisinde olduğu görülmektedir (MEB, 2016; OECD, 2016; Schleicher, 2020; TIMSS, 2016). Oysa ülkelerin hedeflerini geliştirmeye ve değiştirmeye yönlendirecek en önemli unsurun sahip olduğu bireylerin iyi birer öğrenen olmaları ile yakından ilgili olduğu bilinmektedir (MEB, 2018). Bu bakımdan öğrencilerin matematik başarıları üzerinde etkili olan faktör gruplarının bilinmesi ve bu doğrultuda çalışmaların yürütülmesi oldukça değerlidir.

Öğrencilerin etkili birer matematik öğreneni olmaları üzerinde çok sayıda faktör grubu olmakla birlikte öğrenme yaklaşımları ile duygusal destek temel faktör grupları arasında gösterilmektedir (Chong, Liem, Huan ve Ang, 2018; Göktepe-Yıldız, 2019; İlhan, Çetin ve Kılıç, 2013; Mullis, Martin, Foy ve Arora, 2012; Sakız, 2017). Matematik alanında yürütülen çalışmalarda öğrencilerin ayrı öğrenme yaklaşımlarını benimsedikleri dolayısıyla farklı öğrenme yaklaşımlarına sahip oldukları bilinmektedir (Göktepe-Yıldız, 2019). Bu bağlamda, öğrencilerin öğrenme yaklaşımlarının yönünün bilinmesi hem program yapıcılarına hem de araştırmacılara kaynak oluşturması açısından önem arz etmektedir. Alanyazın incelendiğinde, öğrenme yaklaşımlarının çoğunlukla bireysel farklılıkların önemini ortaya koyduğu, öğrenen ile ortam arasındaki ilişkiyi esas aldığı görülmektedir (Newble ve Entwistle, 1986; Ramsden, 2002; Zhang, 2000). Bireylerin öğrenme yaklaşımları öğrenme ortamının niteliğine göre farklılık gösterebilmektedir (Ekinci, 2015; Marshall ve Case, 2005). Bu kapsamda öğrenme yaklaşımı, öğrencinin niyetine bağlı olarak ortaya çıkan yönelimi olarak ifade edilmektedir (Ekinci, 2009). Öğrenmenin nasıl gerçekleştiği sorusuyla yola çıkan bu yaklaşım, öğrenme ortamına ve işin doğasına göre farklılıklar göstermektedir (Biggs ve Moore, 1993). Nitekim öğrenme yaklaşımların kuramsal yapısı başlangıçta derinlemesine ve yüzeysel öğrenme olarak incelenmiş ancak ilerleyen yıllarda stratejik öğrenme yöneliminin de eklenmesiyle üç boyutta ele alınmaya başlanmıştır (Biggs, 1996; Ekinci, 2015; Ramsden, 2002). Öğrenciler farklı öğrenme yaklaşımları ve başarı düzeylerine sahiptirler. Bazı öğrenciler derinlemesine, bazıları stratejik, bazıları da yüzeysel öğrenme yaklaşımlarını sıklıkla tercih etmektedir (Entwistle ve Tait, 1990). Bu durum birçok araştırmacı tarafindan yıllardır araştırılmakta ve öğrenme yaklaşımların bireyler üzerindeki etkisinin neler olduğu belirlenmeye çalışılmaktadır. Bu kapsamda, öğrenme yaklaşımları ile öğrenme ortamlarının önemli değişkenlerinden birisi olan öğretmen duygusal desteği hakkındaki bilgiler kuramsal çerçevede ele alınmıştır.

\section{Kuramsal Çerçeve}

Bu bölümde öğrenme yaklaşımları; derinlemesine, yüzeysel ve stratejik öğrenme yaklaşımları olarak ele alınmış ve öğretmen yapıcı duygusal desteğin önemi ilgili literatür ışığında açıklanmaya çalışılmıştır.

\section{Öğrenme Yaklaşımları}

Öğrenme yaklaşımı öğrencilerin niyetlerine bağlı olarak derinlemesine, yüzeysel ve stratejik öğrenme yaklaşımlarından birisini ağırlıklı olarak tercih etme durumudur (Ekinci, 2009). Derinlemesine öğrenme yaklaşımı yeni karşılaşılan bir öğrenme durumunu eleştirel bakış açısıyla var olan bilgilerle 
ilişkilendirme aynı zamanda anlam aramaya ve oluşturmaya yönelme süreci olarak ifade edilmektedir (Biggs, 1987; Ekinci, 2009; 2015). Derinlemesine öğrenme yaklaşımını benimseyen öğrenciler; öğrenme sürecine aktif olarak katılır, öğrenme konusuna değer verir, çıkarımda bulunur ve sahip oldukları deneyimlerle öğrendiklerini ilişkilendirir (Beydoğan, 2007; Byrne, Flood ve Willis, 2002; Ramsden, 1987). Bu öğrenciler aynı zamanda öğrenmeye karşı olumlu bir bakış açısına sahiptir (Biggs, 1996). Yüzeysel öğrenme yaklaşımı bir konuyu derinlemesine anlamaya çalışmadan kopuk bilgi parçaları şeklinde öğrenmeye çalışmaktır (Ekinci, 2009). Yüzeysel öğrenme yaklaşımına sahip öğrencilerin tipik özellikleri arasında bilinçli bir çaba içinde olmama, yeni fikirleri yorumlamada güçlükler yaşama, bilgiyi ezberlemeyi tercih etme ve sadece dersi geçmek için gayret gösterme yer almaktadır (Beydoğan, 2007; Biggs ve Moore, 1993; Ekinci, 2009; Göktepe-Yıldız, 2019; Ramsden, 2002). Bu bakımdan bu öğrenme yaklaşımını benimseyen öğrencilerin öğrenme çıktıları düşük nitelikli ve anlamlı öğrenmeden daha çok sinavlardan yeterli geçme notunu almaya yöneliktir (Biggs, 1996; Ekinci, 2015; Ramsden, 2002; Trigwell ve Prosser, 1991; Zhang, 2000). Stratejik öğrenme yaklaşımı ise anlam arama ve oluşturma niyeti ile değil başarılı olma niyeti ile hareket etme durumudur (Ekinci, 2009). Bu tip öğrenme yaklaşımına sahip öğrenciler rekabete dayalı bir motivasyon içinde olurlar, algısını hızlandıracak kaynaklara yönelirler, değerlendirmeci ve 1srarcı bir tutum sergilerler (Beydoğan, 2007; Entwistle ve Tait, 1990; Entwistle ve McCune, 2004; Ramsden, 1985; Reid, Duvall ve Evans, 2007).

Derinlemesine öğrenme yaklaşımını tercih eden öğrenciler genellikle bir amaç doğrultusunda hareket ederler, günlük yaşam durumları ile öğrendikleri arasında bağ kurarlar ve öğrenme içeriklerini uyumlu bir biçimde yapılandırırlar (Ramsden, 2002). Yüzeysel öğrenmede öğrenciler ise öğrenmeyi dışsal bir etki olarak değerlendirirler ve çok fazla zihinsel aktivite içeren etkilendikleri yapmaktan kaçınırlar (Biggs, 1996; Ramsden, 2002). Dolayısıyla en az sorun çıkaracak şekilde işi tamamla niyeti taşırlar (Ekinci, 2009). Stratejik öğrenme yaklaşımını kullanan öğrenciler ise daha çok öğrenme ortamının etkisi altında kalırlar (Newble ve Entwistle, 1986). Bu öğrenme yaklaşımını benimseyen öğrenciler çoğunlukla uygun öğrenme materyallerini ve kaynaklarını kullanmayı tercih ederler (Beydoğan, 2007). İlgili alanyazın incelendiğinde, öğrencilerin öğrenme yaklaşımlarını etkileyen çok sayıda faktör grubu olduğu dikkat çekmektedir. Başta ders içeriği olmak üzere akademik başarı, cinsiyet, öğrenme ortamı, sınıf düzeyi, geçmiş yaşantılar ve deneyimler, ön bilgi, öz-yeterlik, denetim odağı, öğrenme stili ile algılama biçimi öğrencilerin öğrenme yaklaşımlarını etkilemektedir (Beşoluk ve Önder, 2010; Beydoğan, 2007; Chong ve diğer., 2018; Ekinci, 2008; 2009; 2015; Feyzioğlu, Feyzioğlu ve Küçükçıng1, 2014; GöktepeYıldız, 2019; Olpak ve Korucu, 2014; Ozan, Köse ve Gündoğdu, 2012; Ünlü, 2017; Feyzioğlu ve Ergin, 2012). Öğrenme yaklaşımı bireyin bir durum karşısındaki performansının ve davranışının nasıl olacağını gösterebilir (Beydoğan, 2007; Chan, 2003; Ramsden, 2002). Bu nedenle, öğrenme yaklaşımı bireyin ders başarısında önemli bir bileşen olarak düşünülmektedir. Örneğin stratejik öğrenme yaklaşımını benimseyen öğrenciler, sınavda çıkacak soruları tahmin etmek için önceden çıkmış soruları inceler ve soruların içeriğine göre değerlendirmeler de bulunur (Duff ve McKinstry, 2007; Ramsden, 2003). Benzer şekilde, derinlemesine öğrenme yaklaşımını benimseyen öğrencilerin içsel olarak güdülenmişlik düzeyi oldukça yüksektir aynı zamanda öğrenme materyallerinden anlamlar çıkartarak önceki bilgileri arasında bağ kurarlar (Diseth ve Martinsen, 2003). Buna karşın yüzeysel öğrenme yaklaşımını benimseyen öğrenciler, ezbere dayalı ve bir amaç olmadan hareket ederler ve mevcut bilgi alanı ile başka bilgi alanları arasında bağ kuramazlar (Beydoğan, 2007; Biggs ve Moore, 1993; Ramsden, 2003). Nitekim yapılan çalışmalarda derinlemesine öğrenme yaklaşımını tercih eden öğrencilerin öğrenme ürünleri yüzeysel ve stratejik öğrenme yaklaşımlarını tercih edenlere göre daha nitelikli olduğu belirtilmektedir (Gordon ve Debus, 2002). Bu bağlamda, hem öğrenme-öğretme süreçlerinin verimliliğini artırmak hem de öğrencilerin performans düzeylerine olumlu katkılar sunmak açısından öğrencilerin öğrenme yaklaşımlarının nasıl olduğunu bilmek önemlidir (Entwistle ve McCune, 2004).

Alanyazın incelendiğinde, düşük düzey başarıya sahip öğrencilerin derinlemesine öğrenme yaklaşım puanları yüksek ve orta düzey başarıya sahip öğrencilerden; yüksek düzey başarıya sahip öğrencilerin ise yüzeysel öğrenme yaklaşım puanları orta ve düşük düzey başarıya sahip öğrencilerin puanlarından daha az olduğu belirtilmektedir (Özkan ve Sezgin-Selçuk, 2014). Benzer şekilde, akademik başarı ile derinlemesine ve stratejik öğrenme yaklaşımlarını tercih etme düzeyleri arasında anlamlı pozitif ilişki, yüzeysel öğrenme yaklaşımını tercih etme düzeyleri arasında anlamlı negatif ilişkinin olduğu 
bulunmuştur (Bahar ve Okur, 2018; Çetin, 2016; Duff, 2004; Ekinci, 2009; Ramsden, 2003). Ayrıca akademik başarı ile derinlemesine öğrenme yaklaşımı arasında pozitif yönde düşük, yüzeysel öğrenme yaklaşımı arasında ise negatif yönde zayıf bir ilişkinin olduğu çalışma sonuçları da bulunmaktadır (Byrne ve diğer., 2002; Sezgin-Selçuk, Çalışkan ve Erol, 2007). Alanyazında, sınıf düzeyi artıkça öğrencilerin derinlemesine ve stratejik öğrenme yaklaşım puanlarının azaldığı (Göktepe-Yıldız ve Özdemir, 2018), öğrenme yaklaşımları ile üniversitelere giriş için başarı ölçütü olarak kabul edilen sınav puanları arasında anlamlı bir farklılık bulunmadığı çalışma sonuçları da mevcuttur (Kanadlı ve Akbaş, 2015). Bu araştırmaların dışında öğrencilerin öğrenme yaklaşımlarını tercih etme düzeyleri cinsiyet, sınıf, düzeyi, öz-yeterlik, okul türü, yaş, konu alanı gibi çeşitli değişkenler açısından da ele alınmıştır (Bahar ve Okur, 2018; Beşoluk ve Önder, 2010; Biggs, 1987; Ekinci, 2015; Feyzioğlu ve diğer., 2014; Marton ve Saljo, 1997; Özgür ve Tosun, 2012; Sezgin-Selçuk ve diğer., 1997; Trigwell ve Prosser, 1991; Zhang, 2000).

\section{Algılanan Öğretmen Yapıcı Duygusal Destek}

Öğrencilerin başarıları üzerinde etkili olan önemli bileşenlerden birisi de öğretmenlerin yapıcı duygusal desteğidir (Sakız, 2017). Duygusal desteğin en önemli yararları arasında bireylerin takdir görmesine, sevilmesine, saygı duyulmasına, kabul edilmesine aynı zamanda kendini güvende hissetmesine yardımc1 olması yer almaktadır (Öztürklü, 2011). Algılanılan yapıcı duygusal destek sayesinde bireyler kendine güvenir, öz yeterlik inançları ile benlik saygısı gelişir ve öğrenme konularına karşı motivasyonu yükselir (Chong ve diğer., 2018; Çivitçi, 2015; House, 1987; Mengi, 2011; Sakız, 2007; Wills ve Shinar, 2000). Ryan ve Deci'ye (2006) göre, algılanılan duygusal destek bireylerin yaşam becerilerinin gelişimine çok önemli katkılar sunmakta ve kritik roller üstlenmektedir. Nitekim algılanan öğretmen yapıcı duygusal desteğin öğrencilerin öğrenmeleri üzerinde önemli bir etkisi bulunmakla birlikte öğrenmelerin bir kısmı da bu desteğin etkisiyle açıklanmaktadır (Gökler, 2007; Langford, Bowsher, Maloney ve Lillis, 1997; Öztürklü, 2011). Etkili bir matematik öğrenimde öğrencilere sunulacak desteğin hem öğrenme ortamına hem de öğrencilerin akademik duygularına/davranışlarına önemli katkıları olduğu bilinmektedir (Krstić, 2015; Lei, Cui ve Chui, 2018; Sakız, Pape ve Woolfolk-Hoy, 2012). Öğretmen yapıcı duygusal desteği, öğretmenin bir öğrenciyle olan ilişkisini de geliştirdiği bilinmektedir (Lei ve diğer., 2018). Stronge’ye (2002) göre, öğretmenlerin öğrencileri üzerinde güçlü aynı zamanda uzun süreli bir etkisi vardır. Öğrencilerin nasıl öğrendikleri, ne öğrendikleri, ne kadar öğrendikleri; birbirleriyle ve çevrelerindeki dünyayla nasıl etkileştiklerini doğrudan etkilerler. Dolayısıyla öğretmen ile öğrenci arasındaki ilişkiler, öğrencilerin sosyal ve akademik gelişimleri için koruyucu bir faktördür (Pianta, Nimetz ve Bennett, 1997). Diğer yandan 1lımlı ve duyarlı öğretmenlere sahip öğrencilerin matematik becerilerinde olumlu gelişmeler olduğu belirtilmektedir (Pianta ve diğer., 1997). Uluslararası kuruluşların düzenli aralıklarla yayınladığı raporlarda da öğretmen desteğinin öğrencilerin matematik başarılarına aynı zamanda gelişim düzeylerine pozitif yönde etki ettiği belirtilmektedir (Mullis ve diğer., 2012). Özellikle alanyazında, öğrencilerin matematik başarıları ile algıladıkları öğretmen yapıcı duygusal desteği konu edinen sınırlı sayıda çalışmaların bulunması (Mengi, 2011; Sakız, 2017) ve bu konunun sıklıkla ihmal edilmiş olması çalışmanın önemli gerekçeleri arasında yer almaktadır. Bu bağlamda, öğrencilerin algıladıkları öğretmen yapıcı duygusal destek ile matematik başarıları arasındaki ilişkinin bilinmesi araştırmaya değer bir konu olarak karşımıza çıkmaktadır.

Alanyazın incelendiğinde, öğretmen yapıcı duygusal desteğin öğrencilerin matematik derslerindeki akademik çabalarına pozitif yönde katkılar sunduğu belirtilmektedir (Sakız ve diğer., 2012). Diğer yandan öğretmen desteğinin öğrencilerin akademik başarıları (Mengi, 2011), akademik duyguları (Lei ve diğer., 2018), kendisinden beklentileri (Kuklinski ve Weinstein, 2001), davranışsal katılımları ve özyeterlikleri (Sakız, 2017), kaygı, umut ile depresyonları (Skinner, Furrer, Marchand ve Kindermann, 2008) üzerinde de etkili olduğu belirtilmektedir. Öğretmen duygusal desteği sınıfın psikolojik iklimini iyileştirir, öğrencilerin derse katılımlarını artırır ve öğrenmeye teşvik eder (Becker ve Luthar, 2002). Nitekim araştırma bulguları da algılanan öğretmen yapıcı duygusal desteğin öğrencilerin akademik benlik kavramı ve öğrenmedeki içsel motivasyonu ile olumlu bir şekilde ilişkili olduğunu ortaya koymaktadır (Skaalvik ve Skaalvik, 2013). Bu duruma dikkat çeken Sakız ve diğer., (2012), algılanan ögretmen yapıcı duygusal desteğin öğrencilerin aidiyet duygusu, akademik zevk, akademik umutsuzluk, 
akademik öz-yeterlik ve matematik derslerindeki akademik çabaları ile önemli ölçüde ilişkili olduğunu belirtmektedir.

Sonuç olarak, öğrenme ortamının önemli sacayaklarından birisi olan öğretmen yapıcı duygusal desteği ile öğrenme sürecini anlamaya yardımcı temel unsur olan öğrenme yaklaşımlarının önemi gün geçtikçe daha iyi anlaşılmaktadır. Özellikle bireysel farklılıkların öğrenmedeki öneminin giderek artması ve öğretim programlarının bireysel farklılıkları dikkate alarak şekillendirilmeye çalışılması bu yönde yapılacak çalışmalara duyulan ihtiyacı daha da artırmaktadır. Öğrencilerin öğrenme yaklaşım tercihleri ile başarıları arasındaki ilişkinin çok sayıdaki çalışmanın çıkış noktasını oluşturması bu konunun önemini daha da belirgin kılmaktadır. Bu çalışmada, matematik dersi ile ilgili öğrencilerin öğrenme yaklaşımlarının ve algıladıkları öğretmen duygusal desteklerinin matematikteki başarılarını etkileme gücü incelendiğinden bu alanda yürütülecek çalışmalara katkı sağlayacağı umulmaktadır. Bu doğrultuda, çalışmanın amacı, altıncı sınıf öğrencilerinin matematik öğrenme yaklaşımları ve algıladıkları öğretmen yapıcı duygusal desteği ile matematik başarıları arasındaki ilişkiyi incelemektir. Bu kapsamda, aşağıdaki sorulara yanıtlar aranmıştır:

1. Altıncı sınıf öğrencilerinin matematik öğrenme yaklaşımları ve algıladıkları öğretmen yapıcı duygusal desteği ile matematik başarıları arasında anlamlı bir ilişki var mıdır?

2. Altıncı sınıf öğrencilerinin matematik öğrenme yaklaşımları ve algıladıkları öğretmen yapıcı duygusal desteğin matematik başarısını yordama gücü nedir?

3. Altıncı sınıf öğrencilerinin algıladıkları öğretmen yapıcı duygusal destek ile derinlemesine, yüzeysel ve stratejik öğrenme yaklaşımlarının matematik başarısı üzerindeki göreli önem sırası nasıldır?

\section{YÖNTEM}

Çalışmanın bu bölümünde, araştırma modeli, çalışma grubu, veri toplama araçları, verilerin toplanması ve verilerin analizi içeriklerine yer verilmiştir.

\section{Araştırma Modeli}

$\mathrm{Bu}$ çalışma, öğrencilerin matematik öğrenme yaklaşımları ve algıladıkları öğretmen yapıcı duygusal desteği ile matematik başarıları arasındaki ilişkileri incelemeyi amaçlayan ve ilişkisel tarama modeline göre gerçekleştirilen betimsel bir çalışmadır. İlişkisel tarama modelleri ise iki ya da daha çok sayıdaki değişken arasındaki değişimin varlığını ve/veya derecesini ölçmeyi amaçlayan araştırma modelleri olarak nitelendirilmektedir (Karasar, 2015).

\section{Çalışma Grubu}

Araştırmanın çalışma grubu, 2018-2019 eğitim-öğretim yılında şehir merkezindeki devlet ortaokulunun altıncı sınıf düzeyinde öğrenim gören 416 gönüllü öğrenciden oluşmaktadır. Öğrencilerin yaş ortalaması 10.7'dir. Öğrencilerin \%54.3'ü (n=226) kız, \%45.7'si $(n=190)$ erkektir. Çalışmada toplamda 421 öğrenci yer almıştır. Ancak üç öğrenci ölçme araçlarının birçok kısımlarını boş bıraktığından, iki öğrenci de bazı ölçme araçları uygulamasının çözümünü tamamlamadığından çalışmadan çıartılmıştır. Uygun örnekleme yönteminin kullanıldığı çalışmada, seçkisiz olmayan uygun bir anlayış tercih edilmiştir. Bu yüzden araştırma grubunun oluşturulmasında uygulanabilir, araştırmacıya yakınlık ve ekonomik bir uygulama yolu izlenmiştir. Nitekim uygun örnekleme yönteminin avantajlı yönleri arasında zaman, para ve işgücü kaybını göz önünde bulundurması gösterilmektedir (Çokluk, Şekercioğlu ve Büyüköztürk, 2014). Bu doğrultuda, öğrencilere çalı̧̧ma hakkında bilgi verilmiş ve çalışmada gönüllülüğe riayet edilmiştir. Ölçme araçları gerekli izinler alındıktan sonra araştırmacı tarafından uygulanmış ve yaklaşık yarım saat sürmüştür.

\section{Veri Toplama Araçları}

Öğrencilerin matematiğe yönelik duygusal destek düzeylerini belirlemek için Sakiz (2017) tarafından geliştirilen tek boyutlu Algılanan Öğretmen Yapıcı Duygusal Destek ölçeği kullanılmıştır. Ölçekteki dokuz madde Öğretmen Duyuşsal Destek ölçeğinden üretilmiştir (Sakiz, 2007). İncelenen literatüre göre, üç madde daha geliştirilmiş ve ölçeğe dâhil edilmiştir. Pilot çalışmanın ardından doğrulayıcı faktör analizi uygulanmış, tüm ölçümlerin kabul edilebilir ölçütlere sahip olduğu belirlenmiştir. 12 maddeden oluşan ölçeğin hesaplanan Cronbach's alpha iç tutarlık katsayısı 0.88 olarak hesaplanmıştır. Çalışma 
kapsamında ölçeğin toplam iç tutarlık katsayısı da hesaplanmış ve 0.92 olarak bulunmuştur. Ölçekte yer alan ifadeler için Hiç doğru değil (1), Doğru değil (2), Biraz doğru (3), Doğru (4), Tamamen doğru (5) olmak üzere beşli Likert tipi bir derecelendirme kullanılmıştır. Ölçeğe ait örnek maddeler ise aşağıda sunulmuştur.

1. Matematik öğretmenim bana şefkatli davranır.

2. Matematik ögretmenim düşünce ve fikirlerime saygı gösterir.

3. Matematik öğretmenim bana karşı sevgi doludur.

Öğrencilerin matematiğe yönelik öğrenme yaklaşım düzeylerini belirlemek Göktepe-Yıldız ve Özdemir (2018) tarafından geliştirilen Matematik Öğrenme Yaklaşımları Ölçeği kullanılmıştır. Ölçme aracı, Derinlemesine Öğrenme Yaklaşımı (DÖY), Yüzeysel Öğrenme Yaklaşımı (YÖY) ve Stratejik Öğrenme Yaklaşımı (SÖY) olmak üzere üç boyuttan oluşmaktadır. 33 maddelik ölçeğin her bir boyutunda 11 madde bulunmaktadır. Ölçme aracının tümüne ait Cronbach's alpha iç tutarlılık katsayısı 0.78 olarak hesaplanmıştır. Ölçeğin alt boyutları için hesaplanan Cronbach's alpha iç tutarlılık katsayıları sırasıyla DÖY için 0.83 , YÖY için 0.78 ve SÖY için 0.83 olarak belirlenmiştir. Ölçeğin üç faktörlü yapısı için yapılan doğrulayıcı faktör analizi sonucunda elde edilen uyum indeksleri $\mathrm{x}^{2} / \mathrm{sd}=4.09$, AGFI=0.83, $\mathrm{GFI}=0.85, \mathrm{CFI}=0.90, \mathrm{SRMR}=0.09$ olarak belirlenmiştir. Çalışma kapsamında da ölçeğin toplam iç tutarlık katsayısı hesaplanmış ve 0.90 olarak hesaplanmıştır. Ölçekte, Kesinlikle katılmıyorum (1), Katılmıyorum (2), Kararsızım (3), Katılıyorum (4) ve Kesinlikle katılıyorum (5) şeklinde beşli Likert tipi bir derecelendirme kullanılmıştır. Ölçeğe ait örnek maddeler ise aşağıda sunulmuştur.

1. Bir matematik konusunu öğrenirken her bir bölümünü ayrıntılı düşünür ve anlamaya çalışırım.

2. Matematik çalışırken soruların çözümlerini anlamadıysam ezberlemeye çalışırım.

3. Matematik sınavlarına genel olarak düzenli bir şekilde hazırlanırım.

Öğrencilerin matematik başarılarını belirlemek için uygulamanın yapıldığı dönemden önceki yılsonu matematik ders notlarının ortalamaları dikkate alınmıştır. Puanlar, en çok 100 en az 0 olabilmektedir. Matematik başarı puanı; sınavlar ile öğrencilerin dönem içinde yaptıkları ödev, proje vb. etkinliklere dayalı performans puanlarının ortalaması ile hesaplanmakta ve öğrencilerin matematik başarılarının belirlenmesinde kullanılmaktadır. Matematik dersi için öğrencilerin yılsonu ders notları başarı ölçütü olarak kabul edildiğinden başarı değişkenini etkileyebilecek faktörleri azaltmak amacıyla sadece bir okuldan veri toplanması hedeflenmiştir. Öğrencilerin yılsonu matematik notu altı matematik yazılısı, altı ders içi etkinliklerine katılım ile iki tane proje notunun ortalamasından oluşmaktadır. Öğrencilerin matematik not ortalamas 67.23 , standart sapmas 16.93 , modu 50, medyan 66 ve varyans 1286.62 'dir.

\section{Verilerin Analizi}

Araştırmada öncelikle veri setine ait normallik analizi yapılmıştır. Yapılan analiz sonucuna göre, çarpıklık değerlerin -0.75 ile 1.08 , basıklık değerlerin ise -0.23 ile 1.07 arasında değiştiği belirlenmiştir. Çarpıklık ve basıklık değerlerinin \pm 1.5 aralığında olması verilerin normal dağılığıma sahip olduğunu göstermektedir (Tabachnick ve Fidell, 2013). Bu doğrultuda, algılanan öğretmen duygusal destek ile matematik öğrenme yaklaşımları arasındaki ilişkiler Pearson momentler çarpımı korelâsyon katsayısı ile hesaplanmıştır. 0 ile \pm 0.29 arasındaki korelasyon değerleri düşük, \pm 0.30 ile \pm 0.59 arasındaki korelasyon değerleri orta ve \pm 0.60 ile \pm 1 arasındaki korelasyon değerleri yüksek düzey ilişki olarak yorumlanmıştır (Büyüköztürk, 2011). Diğer yandan regresyon analizi yapılmadan önce veri setinin çok değişkenli analizler için uygun olup olmadığı incelenmiştir. Bu kapsamda, verilerin normallik analizi, bağımsız değişken ile yordayıcı değişkenler arasında doğrusal bir ilişkinin bulunup bulunmadığı, bağımsız değişkenler arasında çoklu bağlantı probleminin olup olmadığı araştırılmıştır. Öncelikle doğrusallık varsayımını güçleştiren uç değerler Mahalanobis uzaklık değerleri ile incelenmiş ve uç değerlere rastlanılmamıştır. Daha sonra saçılma diyagramı matrisleri incelenmiş, çok değişkenli normallik ve doğrusallığın büyük ölçüde sağlandığı anlaşılmıştır. Son olarak, varyans artış faktörleri (VIF), durum indeksi (CI) ve tolerans değerleri (TV) incelenerek bağımlı ve bağımsız değişkenler arasında çoklu bağlantı probleminin bulunup bulunmadığına bakılmıştır. Varyans artış faktörlerinin 10'a eşit veya daha büyük olması, durum indeksinin 30'a eşit ve daha büyük olması ve tolerans değerlerinin 0.10 'a eşit veya daha küçük olması çoklu bağlantı problemine işaret etmektedir (Çokluk ve diğer., 2014). Veri setinin VIF değerleri 1.01-2.60, CI değeri 20.59 ve TV değerleri ise $0.38-0.98$ arasında değerler almıştır. Elde 
edilen değerlere göre, bağımsız değişkenler arasında çoklu bağlantı probleminin olmadığı söylenebilir. Sonuç olarak, 416 katılımcının verileri ile analizler gerçekleştirilmiştir. Verilerin analiz edilmesinde ise SPSS 22.0 paket programından yararlanılmıştır.

\section{BULGULAR}

Çalışmanın bu bölümünde, ölçme araçlarına ait betimsel değerler, algılanan öğretmen yapıcı duygusal destek ile matematik öğrenme yaklaşımları arasındaki korelâsyon katsayılarına ve çoklu doğrusal regresyon analiz sonuçlarına yer verilmiştir.

Tablo 1. $A \ddot{O} Y D D, D O ̈ Y, Y O ̈ Y, S O ̈ Y$ ve matematik başarısı arasındaki korelâsyon değerleri

\begin{tabular}{lcccccccc}
\hline Değişkenler & Ortalama & Sd. & Toplam & AÖYDD & DÖY & YÖY & SÖY & BaşarI \\
\hline AÖYDD & 3.63 & 0.94 & 1513.67 & 1 & & & & \\
DÖY & 3.59 & 0.79 & 1494.82 & $0.39^{*}$ & 1 & & & \\
YÖY & 3.06 & 0.72 & 1276.09 & 0.02 & $0.08^{*}$ & 1 & & \\
SÖY & 3.67 & 0.99 & 1528.45 & $0.40^{*}$ & $0.77^{*}$ & $0.10^{*}$ & 1 & \\
Başar1 & 67.23 & 16.93 & 27970.00 & $0.36^{*}$ & $0.40^{*}$ & $-0.15^{*}$ & $0.41^{*}$ & 1
\end{tabular}

$\mathrm{N}=416$; * $p<0.05$; AÖYDD: Algılanan Öğretmen Yapııı Duygusal Destek; DÖY: Derinlemesine Öğrenme Yaklaşımı; YÖY: Yüzeysel Öğrenme Yaklaşımı; SÖY: Stratejik Öğrenme Yaklaşımı

Tablo 1 incelendiğinde, matematik öğrenme yaklaşımları, algılanan öğretmen yapıcı duygusal destek ile matematik başarısı arasında farklı düzeylerde anlamlı ilişkiler bulunmuştur. Elde edilen bulgulara göre, matematik başarısı ile öğretmen duygusal destek $(\mathrm{r}=0.36, p<0.05)$, derinlemesine öğrenme yaklaşımı $(\mathrm{r}=0.40, p<0.05)$ ve stratejik öğrenme yaklaşımı $(\mathrm{r}=0.41, p<0.05)$ arasında orta düzeyde pozitif yönlü anlamlı ilişkiler bulunmuştur. Diğer yandan matematik başarısı ile yüzeysel öğrenme yaklaşımı $(\mathrm{r}=-0.15$, $p<0.05)$ arasında ise düşük düzeyde negatif yönlü anlamlı bir ilişsi tespit edilmiştir. Algılanan öğretmen duygusal destek ile öğrencilerin matematik öğrenme yaklaşımlarının matematik başarısını ne şekilde yordadığını incelemek için eş zamanlı çoklu doğrusal regresyon analizi gerçekleştirilmiştir (Tablo 2).

Tablo 2. Algılanan ögrretmen yapıcı duygusal destek ve matematik öğrenme yaklaşımlarının matematik başarısinı yordamasina ilişkin çoklu regresyon analiz sonuçları

\begin{tabular}{lccccccc}
\hline Değisikenler & B & Std. Hata & Beta $(\boldsymbol{\beta})$ & $\mathbf{t}$ & $\mathbf{p}$ & İkili r & Kısmi r \\
\hline Sabit & 40.74 & 4.65 & & 8.75 & $0.00^{*}$ & & \\
AÖYDD & 3.78 & 0.84 & 0.21 & 4.48 & $0.00^{*}$ & 0.36 & 0.21 \\
DÖY & 3.72 & 1.45 & 0.17 & 2.56 & $0.01^{*}$ & 0.40 & 0.12 \\
YÖY & -4.51 & 1.00 & -0.19 & -4.51 & $0.00^{*}$ & -0.15 & -0.21 \\
SÖY & 3.59 & 1.16 & 0.21 & 3.08 & $0.00^{*}$ & 0.41 & 0.15 \\
\hline
\end{tabular}

$\mathrm{R}=0.51 \quad \mathrm{R}^{2}=0.26$

$\mathrm{F}_{(4,411)}=36.35 \quad * p<0.05$

Tablo 2 incelendiğinde, öğrencilerin algıladıkları öğretmen yapıcı duygusal destek ile matematik ögrenme yaklaşımının alt boyutları olan derinlemesine, yüzeysel ve stratejik öğrenme yaklaşımları matematik başarısı üzerinde anlamlı bir ilişki sergilemiştir $\left(\mathrm{R}=0.51 ; \mathrm{R}^{2}=0.26 ; \mathrm{F}_{(4,411)}=36.35 ; p<0.05\right)$. $\mathrm{Bu}$ değişkenler birlikte değerlendirildiğinde, matematik başarısındaki toplam varyansın \%26'sını açıklamışıı. Standartlaştırılmış regresyon katsayılarına göre, yordayıcı değişkenlerin matematik başarıs1 üzerindeki artan yönde göreli önem sırası; algılanan öğretmen yapıcı duygusal destek $(\beta=0.21)$, stratejik öğrenme yaklaşımı $(\beta=0.21)$, derinlemesine öğrenme yaklaşımı $(\beta=0.17)$ iken azalan yönde yüzeysel öğrenme yaklaşımı $(\beta=-0.19)$ olmuştur. Regresyon eşitliğinde yer alan standartlaştırılmış katsayısı (B) matematik başarısındaki değişimi ifade etmektedir. Buna göre, diğer yordayıcılar sabit tutulduğunda algılanan öğretmen yapıcı duygusal destek boyutundaki bir standart sapma yükseliş matematik başarısında 3.78'lik yükselişin olmasına sebep olmaktadır. Benzer biçimde, derinlemesine öğrenme yaklaşımında 3.72'lik ve stratejik öğrenmede 3.59'luk yükselişe, yüzeysel öğrenme yaklaşımında 4.51'lik düşüşe neden olmaktadır. Yordayıcı değişkenlerin kısmi korelasyon katsayıları incelendiğinde en yüksek pozitif kısmi korelasyon değerine sahip değişken algılanan ögretmen yapıcı duygusal destek $(r=0.21)$ olurken en düşük kısmi korelasyon değerine sahip değişken derinlemesine öğrenme yaklaşımı $(\mathrm{r}=0.12)$ olmuştur. Diğer yandan yüzeysel öğrenme yaklaşımı ise 
negatif yönde ( $\mathrm{r}=-0.21)$ kısmi korelasyon değerine sahiptir. Ayrıca katsayıların anlamlılık düzeyleri incelendiğinde, yordayıcı değişkenlerin tamamının matematik başarısının anlamlı yordayıcıları olduğu belirlenmiştir.

\section{SONUÇ, TARTIŞMA VE ÖNERILER}

Çalışma kapsamında altıncı sınıf öğrencilerinin algıladıkları öğretmen yapıcı duygusal destek, matematik öğrenme yaklaşımları (derinlemesine, yüzeysel ve stratejik) ile matematik başarıları arasındaki ilişki ele alınmıştır. Çalışmanın bulguları, öğrencilerin matematik başarıları ile algıladıkları öğretmen yapıcı duygusal destek, derinlemesine, yüzeysel ve stratejik öğrenme yaklaşımları arasında anlamlı ilişkilerin olduğuna işaret etmektedir. Değişkenler arasındaki ilişkilerin varlığı incelendiğinde matematik başarısı ile algılanan öğretmen yapıcı duygusal destek, derinlemesine ve stratejik öğrenme yaklaşımları arasında pozitif, yüzeysel öğrenme yaklaşımı arasında ise negatif yönde anlamlı ilişkilerin olduğu görülmektedir. $\mathrm{Bu}$ bulgulara göre, öğretmenlerin öğrencilerine yönelik yapıcı duygusal desteği ile öğrencilerin öğrenme yaklaşım tercihlerinin matematik başarıları ile ilişkili olduğu söylenebilir. Nitekim yapılan çoklu regresyon analizi sonucuna göre, gerek algılanan öğretmen yapıcı duygusal destek gerekse matematik öğrenme yaklaşım tercihleri matematik başarısının anlamlı birer yordayıcıları olmuştur. Bu bulgular, ilgili alanyazında dile getirilen öğrencilerin başarıları üzerinde öğretmen desteği ile öğrenci yaklaşım tercihleri önemli bir faktördür söylemleriyle örtüşmektedir (Bahar ve Okur, 2018; Biggs, 1997; Çetin, 2016; Çivitçi, 2015; Duff, 2004; Ekinci, 2009; Gökler, 2007; Langford ve diğer., 1997; Öztürklü, 2011; Ramsden, 2003; Sakız ve diğer., 2012). Bu minvalde, öğrencilerin matematik başarılarında algıladıkları ögretmen yapıcı duygusal desteğin yönü ile öğrenme yaklaşım tercihlerinin önemli bir yer tuttuğu söylenebilir. Bu bakımdan özellikle matematik öğretmenlerin derslerinde öğrencilerinin öğrenme yaklaşım tercihlerini dikkate alması ve destekleri ile onlara yardımcı olması oldukça değerlidir. Çünkü öğrenme yaklaşımlarında yaşanan bireysel farklılıkların başarıyı da önemli ölçüde etkilediği sıklıkla dile getirilmektedir (Diseth ve Martinsen, 2003). Bu araştırmanın bulguları da öğrencilerin matematik öğrenme yaklaşım tercihlerinde bireysel farklılıklar önemlidir anlayışını doğrulamaktadır. Bu yüzden öğrencilerin etkili birer matematik öğreneni olmalarında onlara sunulacak öğrenme materyalin niteliği ile öğretmen desteğinin rolü önemli bir faktördür. Nitekim stratejik ve derinlemesine öğrenme yaklaşımının matematik başarısı üzerindeki pozitif etkisi dikkate alındığında, bu öğrenme yaklaşımlarını tercih eden öğrencilerin genellikle başarıyı uygun düzeye çıkarmak için öğrenme materyalini ve zamanını etkili kullandıkları bilinmektedir (Entwistle ve Tait, 1990; Marton ve Saljo, 1997; Ramsden, 1987). Ayrica bu tip öğrenme yaklaşımlarını benimseyen öğrenciler olabildiğince yüksek başarı elde etme gayreti içinde olmaktadır (Beydoğan, 2007). Dolayısıyla stratejik ve derinlemesine öğrenme yaklaşımını benimseyen öğrencilerin matematikte başarılı olmaları da beklenmesi gereken bir durumdur. Nitekim elde edilen bulgularda, bu öğrenme yaklaşımların matematik başarısının önemli yordayıcıları olduğunu göstermektedir. Özellikle öğrenme yaklaşımlarından stratejik öğrenme yaklaşımının matematik başarısını önemli ölçüde etkilemesi ders öğretmenlerine önemli görevler yüklemektedir. Çünkü stratejik öğrenme yaklaşımını benimseyen öğrenciler öğrenmenin doğasından daha çok öğrenme ortamından etkilenmektedir (Entwistle ve McCune, 2004). Bu bağlamda, matematik öğretmenlerinin 1lımlı ve tutarlı davranışları öğrencilerin stratejik ya da derinlemesine öğrenme yaklaşımlarını daha çok tercih etmelerine kapı aralayabilir. Nitekim alanyazında, öğrenmelerin bir kısmında algılan öğretmen desteğinin önemli rolü olduğuna vurgu yapmaktadır (Gökler, 2007; Langford, Bowsher, Maloney ve Lillis, 1997; Öztürklü, 2011).

Araştırmanın dikkat çekici bulgularından birisi de yüzeysel öğrenme yaklaşımına sahip öğrencilerin matematik başarıları ile azalan yönde bir ilişki sergilemesidir. Bu bulguya göre, matematik dersinde yüzeysel öğrenme yaklaşımını tercih eden öğrencilerin matematik dersini anlamak için yeterli bir çaba içinde olmadıkları ya da anlamlı öğrenmeden uzak bir tutum içinde oldukları söylenebilir. Nitekim bu tip öğrenme yaklaşımına sahip öğrencilerin en belirgin özellikleri arasında bilgiyi ezberlemeyi tercih etme ve bilinçli bir çaba içinde olmama yer almaktadır (Beydoğan, 2007; Biggs, 1996; Ekinci, 2009; Ramsden, 2002). Yüzeysel öğrenme yaklaşımını tercih eden öğrenciler, genellikle dersten geçmek için gerekli asgari notu almayı yeterli görmektedir (Ekinci, 2009). Bundan dolayı matematik öğretmenleri öğrencilerinin seviyelerine uygun öğrenme materyalleri hazırlamalı, öğrenme sürecinde onları cesaretlendirmeli ve onlara rehberlik etmelidir. Entwistle ve McCune'ye (2004) göre, öğrenme ortamının 
niteliği, öğreticinin tutumu, öğretim yöntem ve teknikler ile öğrenme içerikleri gibi birçok faktör grubu öğrencilerin öğrenme yaklaşım tercihlerini etkileyebilir. Dolayısıyla matematik öğretmenlerinin öğrencilerine yönelik olumlu geri bildirimleri oldukça önemlidir. Nitekim yapıc1/olumlu bir geri bildirim, öğrencilerin hem benlik saygılarının gelişimine katkı sağlar hem de öğrenme konularına karşı motivasyonlarını artırır (Chong ve diğer., 2018; Çivitçi, 2015; Sakız, 2017; Wills ve Shinar, 2000). Aynı zamanda araştırmanın bu bulgusu, algılanan öğretmen duygusal desteğin öğrencilerin matematik öğrenme yaklaşımlarındaki rolüne de vurgu yapmaktadır. Öyle ki eğer matematik öğretmenleri öğrencilerinin öğrenme gayretlerini desteklerse, onlara sevildiğini ve takdir görüldüğünü hissettirirse bu durum stratejik ya da derinlemesine öğrenme yaklaşımlarının öğrenciler tarafından daha çok tercih edilmesine neden olabilir. Bu sayede öğrenciler, matematik derslerine daha aktif bir katılım sağlarlar, dersi anlama gayreti içinde olurlar, öğrenmeye karşı 1srarcı bir tutum sergilerler ve her şeyden önemlisi zor olarak algılanan bu derse karşı olumlu bir tutum geliştirebilirler (Ekinci, 2009; Entwistle ve Tait, 1990; Ramsden, 1985). Nitekim öğrenme yaklaşım tercihinde öğretmenin öğrenciye karşı tutumunun önemli bir etkisinin olduğu bilinmektedir (Sezgin ve diğer., 2007). Özellikle yüzeysel öğrenme yaklaşımını benimseyen öğrencilerin yeni fikirleri anlamlandırmada ve yorumlamada güçlükler yaşaması matematik öğretmenlerine de önemli sorumluluklar yüklemektedir (Beydoğan, 2007). Öğretmenlerin öğrencilerini desteklemesi, ulaşılabilir hedefler koyması, başarılabilir duygusunu hissettirmesi ve mevcut bilgi ile yeni öğrenilen arasında bağ kurulmasına yardımcı olması onların bazı sorumlulukları arasında gösterilebilir. Bu sayede, matematik öğretmenleri öğrencilerinin öğrenme yaklaşım tercihlerini uygun yöntem ve stratejileri de işe koşarak etkileyebilir. Dolayısıyla öğrenme ortamının durumsal özelliklerinin yanı sıra öğreticinin öğrenen üzerindeki etkisi dikkate alındığında, öğrenme yaklaşım tercihinin öğrencilerin matematik başarılarında da oldukça önemli olduğu söylenebilir.

Araştırmanın bir diğer bulgusu, öğrencilerin öğretmen yapıcı duygusal destekleri ile stratejik öğrenme yaklaşım tercihlerinin göreli önem sırasının ilk basamağında yer almasıdır. Bu sonuçlar, matematik başarısında bu iki değişkenin önemli bir yer edindiğini göstermektedir. Nitekim alanyazında, öğretmen duygusal desteğin öğrencilerin derse katılımları ve öğrenmeleri üzerinde pozitif bir etkisinin olduğu belirtilmektedir (Becker ve Luthar, 2002). Özellikle etkili bir matematik öğretiminde öğretmenlerin işlevsel duygusal desteğe sahip olması olumlu sınıf ikilimi oluşmasının yanı sıra öğrenci başarısını da olumlu yönde etkilemektedir (Krstić, 2015; Sakız ve diğer., 2012). Diğer yandan stratejik öğrenme yaklaşımına sahip öğrencilerde başarılı olmak için kendilerini motive ederler ve mümkün olan en yüksek notu almak için öğrenme ortamını düzenlerler (Diseth ve Martinsen, 2003). Aynı zamanda bu öğrenme yaklaşımını benimseyen öğrencilerin öncelikleri arasında; yüksek not alma, rekabetçi ve başarılı olma yer almaktadır (Ekinci, 2009; Reid ve diğer., 2007). Dolayısıyla hem algılanan öğretmen yapıcı duygusal desteğin hem de stratejik öğrenme yaklaşımının matematik başarısında önemli bir etkiye sahip olması alanyazında dile getirilen açıklamalarla da örtüşmektedir (Duff ve McKinstry, 2007; Lei ve diğer., 2018; Ramsden, 1987; Sakız, 2007; Stronge, 2002). Bu doğrultuda, matematik öğretmenlerinin bireysel farklılıkları dikkate alması aynı zamanda yüzeysel öğrenme yaklaşıma sahip öğrencileri için stratejik ya da derinlemesine öğrenme yaklaşımlarını kullanabileceği öğrenme ortamları tasarlamaları çalışmanın önerileri arasında gösterilebilir. Bu bakımdan matematik öğretmenleri öğrenci merkezli bir anlayışla hareket ederek, öğrencilerini cesaretlendirmeli ve öğrenme durumlarını dikkate alarak uygun rehberlik faaliyetleri yürütmelidir.

Sonuç olarak, toplumların geleceğini şekillendirecek bireylerin iyi birer matematik okuryazarı olmasının önemi nedeniyle, öğrencilerin matematik başarılarını etkileyen faktörlerin neler olduğunun incelenmesi çok sayıdaki araştırmanın çıkış noktasını oluşturmuştur (Mullis ve diğer., 2012; OECD, 2016). Özellikle öğrenme yaklaşımının öğrenci performansını doğrudan etkilediğ düşünüldüğünde, yaşam boyu öğrenme sürecinde dikkate alınması ve incelenmesi gereken bir konudur (Özgür ve Tosun, 2012). Çalışmadan elde edilen bulgulara göre, algılanan öğretmen yapıcı duygusal desteği ile öğrenme yaklaşım tercihleri öğrencilerin matematik başarılarını önemli ölçüde etkilemektedir. Dolayısıyla olumlu yönde öğretmen duygusal desteği alan aynı zamanda derinlemesine ve stratejik öğrenme yaklaşımlarını benimseyen öğrencilerin matematik başarıları da artmaktadır. Bu doğrultuda, altıncı sınıf öğrencilerinin matematik başarılarının artmasında veya arzu edilen seviyenin üzerine çıkartılmasında derinlemesine, yüzeysel ve stratejik öğrenme yaklaşımlarının yanı sıra öğretmen desteğinin de dikkate alması yararlı olabilir. 
Çalışmanın bu yönüyle alanda yürütülecek benzer çalışmalara ve program yapıcılara katkı sağlaması umulmaktadır. Diğer yandan çalışmanın birtakım sınırlılıkları da bulunmaktadır. Araştırmanın en önemli sınırlığı matematik başarısı değişkeni dikkate alındığı için çalışma grubunun tek bir kurumla sınırla tutulması olmuştur. Benzer bir çalışma, başarı değişkeni de dikkate alınarak farklı kurum ya da tüm ortaokul düzeyi öğrencilerini kapsayacak şekilde yürütülebilir. Bir diğer sınırlılık ise çalışmanın tek bir sınıf düzeyi ile sınırlı kalmasıdır. Benzer bir çalışma, farklı sınıf düzeylerini de kapsayacak şekilde yürütülebilir. Bunun yanı sıra farklı yerleşim birimlerini (köy, kasaba, ilçe) de kapsayacak şekilde benzer çalışmalar yürütülebilir. Çalışmada ağırlıklı olarak nicel veriler kullanılmıştır. Benzer türdeki çalışmalar nitel verilerle de desteklenebilir.

\section{KAYNAKÇA}

Bahar, H. H. ve Okur, M. (2018). Öğretmen adaylarının ders çalışma yaklaşımlarının akademik başarıyı yordama gücü. Cumhuriyet International Journal of Education, 7(3), 307-318.

Becker, B. E., \& Luthar, S. S. (2002). Social-emotional factors affecting achievement outcomes among disadvantaged students: Closing the achievement gap. Educational Psychologist, 37(4), 197-214.

Beşoluk, Ş. ve Önder, İ. (2010). Öğretmen adaylarının öğrenme yaklaşımları, öğrenme stilleri ve eleştirel düşünme eğilimlerinin incelenmesi. Ilköğretim Online, 9(2), 679-693.

Beydoğan, Ö. (2007). Derinliğine ve yüzeysel öğrenmede kavram haritaları ve şemaların işlevi. Milli Eğitim, 173, 258-270.

Biggs, J. B. (1987). Student approaches to learning and studying. Hawthorn, Victoria: Australian Council for Educational Research.

Biggs, J. B., \& Moore, P. J. (1993). The process of learning. Sydney: Prentice-Hall Australia.

Biggs, J. B. (1996). Enhancing teaching through constructive alignment. Higher Education, 32(3), 347364.

Büyüköztürk, Ş. (2011). Sosyal bilimler için veri analizi el kitabı (15.Baskı). Ankara: Pegem Akademi.

Byrne, M., Flood, B., \& Willis, P. (2002). The relationship between learning approaches and learning outcomes: A study of Irish accounting students. Accounting Education, 11(1), 27-42.

Chan, K. (2003). Hong Kong teacher education students' epistemological beliefs and approaches to learning. Research in Education, 69(1), 36-50.

Chong, W. H., Liem, G. A. D., Huan, V. S., Kit, P. L., \& Ang, R. P. (2018). Student perceptions of selfefficacy and teacher support for learning in fostering youth competencies: Roles of affective and cognitive engagement. Journal of Adolescence, 68, 1-11.

Çetin, B. (2016). Approaches to learning and age in predicting college students' academic achievement. Journal of College Teaching and Learning (Online), 13(1), 21-28.

Çivitçi, A. (2015). The moderating role of positive and negative affect on the relationship between perceived social support and stress in college students. Educational Sciences: Theory and Practice, 15(3), 565-573.

Çokluk, Ö., Şekercioğlu, G. ve Büyüköztürk, Ş. (2014). Sosyal bilimler için çok değişkenli istatistik: SPSS ve LISREL uygulamaları (3. Baskı). Ankara: Pegem Akademi.

Diseth, A., \& Martinsen, Ø. (2003). Approaches to learning, cognitive style, and motives as predictors of academic achievement. Educational Psychology, 23(2), 195-207.

Duff, A. (2004). The revised approaches to studying inventory (RASI) and its approach in management education. Active Learning in Higher Education, 5(1), 56-72. 
Duff, A., \& McKinstry, S. (2007). Students' Approaches to Learning. Issues in Accounting Education, 22(2), 183-214.

Ekinci, N. (2008). Üniversite ögrrencilerinin ögrenme yaklaşımlarının belirlenmesi ve öğretme-ögrrenme süreci değişkenleri ile iliş̧kileri. Yayımlanmamış doktora tezi, Hacettepe Üniversitesi, Ankara.

Ekinci, N. (2009). Üniversite öğrencilerinin öğrenme yaklaşımları. Eğitim ve Bilim, 34(151), 74-88.

Ekinci, N. (2015). Öğretmen adaylarının öğrenme yaklaşımları ve öğretmen özyeterlik inançları arasındaki ilişki. Hacettepe Üniversitesi Eğitim Fakültesi Dergisi, 30(1), 62-76.

Entwistle, N. J., \& Tait, H. (1990). Approaches to learning, evaluations of teaching, and preferences for contrasting academic environments. Higher Education 19, 169-194.

Entwistle, N., \& McCune, V. (2004). The conceptual bases of study strategy inventories. Educational Psychology Review, 16(4), 325-346.

Feyzioğlu, E. Y. ve Ergin, Ö. (2012). 5E öğrenme modelinin kullanıldı̆̆ öğretimin yedinci sınıf öğrencilerinin öğrenme yaklaşımlarına etkisi. Necatibey Eğitim Fakültesi Elektronik Fen ve Matematik Ĕ̈itimi Dergisi, 6(1), 23-54.

Feyzioğlu, E. Y., Feyzioğlu, B. ve Küçükçıngı, A. (2014). Fen bilgisi öğretmen adaylarının fen öğretimine yönelik zihinsel modelleri, öz yeterlik inançları ve öğrenme yaklaşımları. Ondokuz Mayls Üniversitesi Ĕgitim Fakültesi Dergisi, 33(2), 404-423.

Gordon, C., \& Debus, R. (2002). Developing deep learning approaches and personal teaching efficacy within a pre-service teacher education context. British Journal of Educational Psychology, 72(4), 483-511.

Gökler, I. (2007). Çocuk ve ergenler için sosyal destek değerlendirme ölçeği Türkçe formunun uyarlama çalışması: Faktör yapısı, geçerlik ve güvenirliği. Çocuk ve Gençlik Ruh Sağlĭğ Dergisi, 14(2), 90-99.

Göktepe-Yıldız, S. ve Özdemir, A. Ş. (2018). Ortaokul öğrencilerinin matematik öğrenme becerilerinin belirlenmesi. Illköğretim Online, 17(3), 1378-1401.

Göktepe-Yıldız, S. (2019). Tasarım temelli matematik uygulamalarının farklı ögrenme yaklaşımlarına sahip ögrencilerin uzamsal yeteneklerine ve 3 boyutlu geometrik düşünme becerilerine etkisinin incelenmesi. Yayımlanmamış doktora tezi. Marmara Üniversitesi, İstanbul.

House, J. S. (1987). Social support and social structure. Sociological Forum, 2(1), 135-146.

İlhan, M., Çetin, B. ve Kılıç, M. A. (2013). Matematik Öğrenme Yaklaşımları Ölçeği'nin (MÖYÖ) geliştirilmesi: Geçerlik ve güvenirlik çalışması. Bartın Üniversitesi Eğitim Fakültesi Dergisi, 2(2), 113-145.

Kanadlı, S. ve Akbaş, A. (2015). Fen bilgisi öğretmen adaylarının epistemolojik inançları, öğrenme yaklaşımları ve LYS puanları arasındaki ilişkiler. Mersin Üniversitesi Eğitim Fakültesi Dergisi, 11(1), 116-131.

Karasar, N. (2015). Bilimsel araştırma yöntemi (28. Baskı). Ankara: Nobel Yayın Dağıtım.

Krstić, K. (2015). Attachment in the student-teacher relationship as a factor of school achievement. Teaching Innovations, 28(3), 167-188.

Kuklinski, M. R., \& Weinstein, R. S. (2001). Classroom and developmental differences in a path model of teacher expectancy effects. Child Development, 72(5), 1554-1578.

Langford, C. P. H., Bowsher, J., Maloney, J. P., \& Lillis, P. P. (1997). Social support: A conceptual analysis. Journal of Advanced Nursing, 25(1), 95-100. 
Lei, H., Cui, Y., \& Chiu, M. M. (2018). The relationship between teacher support and students' academic emotions: A meta-analysis. Frontiers in Psychology, 8, 1-12.

Marshall, D., \& Case, J. (2005). Approaches to learning' research in higher education: A response to Haggis. British Educational Research Journal, 31(2), 257-267.

Marton, F., \& Saljo, R. (1997). Approaches to learning. In Marton, F., Hounsell, D., Entwistle, N. (Ed.). The experience of learning. Edinburgh: Scottish Academic Press.

Mengi, S. (2011). Ortaögretim 10. ve 11. sınf ögrencilerinin sosyal destek ve özyeterlik düzeylerinin okula bağlllıkları ile ilişkisi. Yayımlanmamış yüksek lisans tezi. Sakarya Üniversitesi, Sakarya.

Milli Eğitim Bakanlığı (MEB) (2016). PISA 2015. OECD ulusal nihai raporu. Ankara: Ölçme, Değerlendirme Sınav Hizmetleri Genel Müdürlüğü.

Mullis, I. V.S., Martin, M. O., Foy, P., \& Arora, A. (2012). TIMSS 2011 international results in mathematics. TIMSS \& PIRLS International Study Center, Lynch School of Education, Boston College Chestnut Hill, MA, USA.

National Council of Teachers of Mathematics (NCTM) (2000). Principles and standards for school mathematics. Reston, VA: Author.

National Council of Teachers of Mathematics (NCTM) (2014). Principles to actions: Ensuring mathematical success for all. Reston, VA: NCTM.

National Research Council (NRC) (2012). A Framework for $k$-12 science education: practices, crosscutting concepts, and core ideas. Washington DC: The National Academic Press.

Newble, D. I., \& Entwistle, N. J. (1986). Learning styles and approaches: implications for medical education. Medical Education, 20(3), 162-175.

Olpak, Y. Z. ve Korucu, A. T. (2014). Öğrencilerin ders çalışma yaklaşımlarının farklı değişkenler açısından incelenmesi. Ahi Evran Üniversitesi Kırşehir Eğitim Fakültesi Dergisi, 15(1), 333347.

Organisation for Economic Co-operation and Development (OECD) (2016). PISA 2015 results in focus. OECD, Paris. http://www.oecd.org/pisa/ adresinden 25 Aralık 2019 tarihinde edinilmiştir.

Ozan, C., Köse, E. ve Gündoğdu, K. (2012). Okul öncesi ve sınıf öğretmenliği öğrencilerinin öğrenme yaklaşımlarının incelenmesi. Eğitim Bilimleri Araştırmaları Dergisi, 2(2), 75-92.

Özgür, H. ve Tosun, N. (2012). Öğretmen adaylarının derin ve yüzeysel öğrenme yaklaşımlarının çeşitli değişkenler açısından incelenmesi. Mehmet Akif Ersoy Üniversitesi Eğitim Fakültesi Dergisi, 24, 113-125.

Özkan, G. ve Sezgin-Selçuk, G. (2014). Lise öğrencilerinin fizik öğrenme yaklaşımlarının belirlenmesi. Necatibey Ĕ̈itim Fakültesi Elektronik Fen ve Matematik Ĕgitimi Dergisi, 8(1), 101-127.

Öztürklü, Ç. (2011). Illköğretim 4 ve 5. sınff ögrrencilerinin sinı öğretmenlerine yönelik duygusal destek davranış algılarının incelenmesi. Yayımlanmamış yüksek lisans tezi. İstanbul Üniversitesi, İstanbul.

Pianta, R. C., Nimetz, S. L., \& Bennett, E. (1997). Mother-child relationships, teacher-child relationships, and school outcomes in preschool and kindergarten. Early Childhood Research Quarterly, 12(3), 263-280.

Ramsden, P. (1985). Student learning research: Retrospect and prospect. Higher Education Research and Development 4(1), 51-69.

Ramsden, P. (1987). Improving teaching and learning in higher education: The case for a relational perspective. Studies in Higher Education, 12(3), 275-286. 
Ramsden, P. (2002). Learnig to teaching in higher education. London and Newyork: Routledge Falmer.

Reid, W. A., Duvall, E., \& Evans, P. (2007). Relationship between assessment results and approaches to learning and studying in year two medical students. Medical Education, 41(8), 754-762.

Ryan, R. M., \& Deci, E. L. (2006). Self-regulation and the problem of human autonomy: Does psychology need choice, self-determination, and will? Journal of Personality, 74(6), 1557-1586.

Sakız, G. (2007). Does teacher affective support matter? An investigation of the relationship among perceived teacher affective support, sense of belonging, academic emotions, academic self-efficacy beliefs, and academic effort in middle school mathematics classroom. Unpublished doctoral dissertation. The Ohio State University, Columbus, OH.

Sakız, G., Pape, S. J., \& Woolfolk-Hoy, A. (2012). Does perceived teacher affective support matter for middle school students in mathematics classrooms? Journal of School Psychology, 50(2), 235255.

Sakız, G. (2017). Perceived teacher affective support in relation to emotional and motivational variables in elementary school science classrooms in Turkey. Research in Science \& Technological Education, 35(1), 108-129.

Schleicher, A. (2020). PISA 2018. Insights and interpretations. https://www.oecd.org/pisa/ adresinden 12 Ocak 2020 tarihinde edinilmiştir.

Sezgin-Selçuk, G., Çalışkan, S. ve Erol, M. (2007). Fizik öğretmen adaylarının öğrenme yaklaşımlarının değerlendirilmesi. Gazi Eğitim Fakültesi Dergisi, 27(2), 25-41.

Skaalvik, E. M., \& Skaalvik, S. (2013). Teachers' perceptions of the school goal structure: Relations with teachers' goal orientations, work engagement, and job satisfaction. International Journal of Educational Research, 62, 199-209.

Skinner, E. A., Furrer, C., Marchand, G., \& Kindermann, T. (2008). Engagement and disaffection in the classroom: Part of a larger motivational dynamic? Journal of Educational Psychology, 100(4), 765-781.

Stronge, J. H. (2002). Qualities of effective teachers. Alexandria, VA: Association for Supervision and Curriculum Development.

Tabachnick, B. G., \& Fidell, L. S. (2013). Using multivariate statistics (6th Ed.). Boston MA: Pearson.

Trends in International Mathematics and Science Study (TIMSS) (2016). Highlights from TIMSS and TIMSS advanced 2015. https://nces.ed.gov/timss/ adresinden 8 Ocak 2020 tarihinde edinilmiştir.

Trigwell, K., \& Prosser, M. (1991). Improving the quality of student learning: the influence of learning context and student approaches to learning outcomes. Higher Education, 22(3), 251-66.

Ünlü, B. (2017). Fen bilgisi ögretmen adaylarının duygusal zekâlarıyla ögrenme yaklaşımları arasındaki ilişsi: Diğer programlarla karşılaştırmalı incelenmesi. Yayımlanmamış yüksek lisans tezi, Kastamonu Üniversitesi, Kastamonu.

Wills, T. A., \& Shinar, O. (2000). Measuring perceived and received social support. In S. Cohen, L. G. Underwood and B. H. Gottlieb (Eds.), Social support measurement and intervention: A guide for health and social scientists (pp. 86-135). New York: Oxford University Press.

Zhang, L. F. (2000). University students' learning approaches in three cultures: An investigation of Bigg's 3p model. The Journal of Psychology, 134(1), 37-55. 